\title{
Fortifying pork liver mixture: Evaluation of protein quality and iron bioavailability - Part 2
}

\author{
Mistura fortificadora a base de fígado suino: \\ avaliação da qualidade protéica e da \\ biodisponibilidade de ferro - Parte 2
}

Silvana Mariana SREBERNICH ${ }^{1}$

Gisele Mara Silva GONÇALVES²

Semíramis Martins Álvares DOMENE

\section{A B S T R A C T}

\section{Objective}

To evaluate the protein quality and iron bioavailability of a fortifying mixture based on pork liver.

\section{Methods}

Determinations of protein efficiency ratio, net protein utilization, true digestibility and hemoglobin regeneration efficiency by depletion and repletion were performed. In the depletion phase, the animals (male Wistar rats) received an iron-free AIN-93G diet and in the repletion phase they received the following diets: standard AIN-93G diet, fortifying mixture and standard diet containing heptahydrated ferrous sulfate for comparison.

\section{Results}

For standard AIN-93G diet and fortifying mixture the results were 3.75 and 4.04 for protein efficiency ratio and 3.53 and 3.63 for net protein retention, showing that the presence of pork liver in the diet promoted an increase in protein efficiency ratio and net protein retention (not statistically significant). True digestibility results obtained with the fortifying mixture (97.16\%) were higher than those obtained with the standard AIN-93G diet (casein), but without significant difference. The hemoglobin regeneration efficiency values obtained for standard AIN-93G diet, fortifying mixture and standard diet containing heptahydrated ferrous sulfate were 50.69, 31.96 and $29.96 \%$, respectively, showing a statistically significant difference between the control (standard AIN-93G

\footnotetext{
1 Pontifícia Universidade Católica de Campinas, Centro de Ciências da Vida, Faculdade de Nutrição. Av. John Boyd Dunlop, s/n., Jd. Ipaussurama, 13060-904, Campinas, SP, Brasil. Correspondência para/Correspondence to: SM SREBERNICH. E-mail: <srebernich@uol.com.br>.

2 Pontifícia Universidade Católica de Campinas, Centro de Ciências da Vida, Faculdade de Farmácia. Campinas, SP, Brasil.

${ }^{3}$ Universidade Federal de São Paulo, Instituto de Saúde e Sociedade, Departamento de Políticas Públicas e Saúde Coletiva. Santos, SP, Brasil.
} 
diet) and test (fortifying mixture and standard diet containing heptahydrated ferrous sulfate) samples, but not between the test samples.

\section{Conclusion}

The fortifying mixture showed a high protein efficiency ratio value of 4.04 and a high relative biological value $(108 \%)$ and it can be added to soups, creams and meats in day-care centers for the prevention of iron-deficiency in children of school age.

Keywords: Feeding strategy. Iron. Micronutrients. Proteins

\section{R E S U M O}

\section{Objetivo}

Avaliar a qualidade protéica e a biodisponibilidade de ferro de uma mistura fortificadora a base de fígado suíno.

\section{Métodos}

Foram determinados coeficiente de eficácia protéica, retenção protéica líquida, digestibilidade verdadeira e de eficiência da regeneração de hemoglobina (depleção e repleção). Na fase de depleção os animais (ratos da linhagem Wistar) receberam dieta (AIN-93G) isenta de ferro e na fase de repleção receberam as dietas: padrão AIN-93G (dietas padrão AIN-93G), mistura fortificadora e dieta-padrão com sulfato ferroso heptahidratado para comparação.

\section{Resultados}

Para dietas padrão AIN-93G e mistura fortificadora os resultados foram respectivamente 3,75 e 4,04 para coeficiente de eficácia protéica e 3,53 e 3,63 para retenção protéica líquida mostrando que a presença de fígado suíno promoveu aumento dos valores de coeficiente de eficácia protéica e retenção protéica líquida (sem diferença estatística). Resultados de digestibilidade verdadeira obtidos com a dieta mistura fortificadora $(97,16 \%)$ foram maiores do que os obtidos com a dietas padrão AIN-93G (caseína), também sem diferença estatística. Os resultados de eficiência da regeneração de hemoglobina para dietas padrão AIN-93G, mistura fortificadora e sulfato ferroso heptahidratado foram respectivamente 50,69; 31,96 e 29,96\% apresentando diferença estatística significativa entre a amostra controle (dietas padrão AIN-93G) e as amostras testes (mistura fortificadora e sulfato ferroso heptahidratado), porém não entre as amostras testes.

\section{Conclusão}

A mistura fortificadora se mostrou com alto coeficiente de eficácia protéica $(4,04)$ e alto valor biológico relativo (108\%) podendo ser adicionada às sopas, cremes, carnes em creches na prevenção e controle da anemia ferropriva em crianças em idade escolar.

Palavras-chave: Estratégia alimentar. Ferro. Micronutrientes. Proteína.

\section{NTRODUCTION}

The use of foods fortified by the addition of nutrients is a strategy for the combat against nutritional deficiencies. Despite the good results observed with fortification programs in terms of a reduced risk to develop specific deficiencies [1], the addition of nutrients to food does not resolve states of multiple deficiencies in a satisfactory manner [2] and may involve risks of overdosing. The fortification of preparations with foods directed at the target audience has advantages by reducing the risk of excessive intake or of insufficient coverage of the nutritional requirements [1] and by simultaneously providing nutrients and bioactive compounds. Another advantage of the use of fortifying ingredients is the possibility of expanding access by preparing food formulations at each target location $[3,4]$.

Among the nutritional deficiencies still persisting today, iron-deficiency anemia is the most important in terms of prevalence, affecting about $30 \%$ of the world population, especially children up to five years of age, a stage of life during which the disease affects more than $40 \%$ of the inhabitants of Latin America [5]. 
Culinary solutions have been already adopted in nutritional studies focusing on anemia, but could also be applied to other nutritional requirements since they combine the complex nutritional matrices represented by foods [6]. Approaches using recipes with foods of high nutritional density in order to combat anemia in Brazil depend on the development and assessment of the potential of these products. Thus, the present study concerns the nutritional evaluation of a pork liver formulation based on the analysis of its iron content and bioavailability and its protein quality.

\section{METHODS}

The description of the pork liver fortifying mixture and the details of its formulation have been previously published [7].

The formulations of the experimental diets are listed in Table 1. They were prepared according to AIN-93G standards [8], containing $12 \%$ protein in order to be isoenergetic and isoproteic. The centesimal composition of the diets was determined in all formulations $[9,10]$

Eighteen 23-day-old newly weaned male albino Wistar rats (Rattus novergicus) initially weighing $45 \mathrm{~g}$ to $50 \mathrm{~g}$ were used for the biological assay. The rats were divided into three groups of six animals, each group receiving one of the experimental diets.

During the 28-day assay, the animals were kept in individual cages under conditions of controlled temperature $\left(25 \pm 2^{\circ} \mathrm{C}\right)$ and a 12 -hour light/dark cycle, with free access to water and to their respective diets.

The protein quality of the experimental diets was evaluated by means of a biological assay as described by Pellet \& Young [11]. Diet consumption and animal weight were recorded every two days for 28 days for the determination of weight gain, food consumption, protein consumption and Feed Efficiency Rate (FER).
The Protein Efficiency Rate (PER), net protein utilization and true digestibility were determined according to the protocol proposed by Hegsted [12].

Iron bioavailability was determined by the Hemoglobin Regeneration Efficiency (HRE) method, repletion protocol, proposed by Fritz et al. [13].

The experimental design was fully randomized and the study was divided into two periods, i.e., depletion and repletion. During the depletion period (28 days), the animal received an iron-free standard AIN-93G diet [8] for the induction of anemia, and during the repletion period, the animals received the vitamin (AIN93-VX) and mineral (AIN-93G-MX) mixtures recommended by the American Institute of Nutrition (AIN) as described by Reeves et al. [8].

Defined ingredient quantities were duly mixed and pelleted (with no heating), forming the test diets (Table 1). All diets used were isocaloric and isoproteic and the quantities of their ingredients were established on a dry basis.

Twenty-one newly weaned male albino Wistar rats (Rattus norvegicus) aged approximately 23 days and weighing $50 \mathrm{~g}$ to $60 \mathrm{~g}$ were used for the assay. The animals were housed in individual cages in a temperature-controlled room $\left(25^{\circ} \mathrm{C} \pm 2^{\circ} \mathrm{C}\right)$ under a $12 / 12$ hour dark/light cycle. The assay consisted of two phases, i.e., depletion and repletion.

Depletion period: the objective of the depletion period was to induce iron-deficiency anemia and to prepare the animals for the repletion phase. The animals received the Standard Diet Without Iron (SDWFe) and deionized water ad libitum for 28 days [14]. At the end of this period, the animals were anesthetized with a ketamine solution $(0.15 \mathrm{~mL} / 100 \mathrm{~g}$ body weight) and blood was collected from the tip of the tail into tubes containing ethylenediaminetetraacetic acid as an anticoagulant and refrigerated at $4^{\circ} \mathrm{C}$ for later hemoglobin [15] and hematocrit [16] 
Table 1. Formulations of the experimental diets offered to rats in the biological assay for the evaluation of protein quality (A) and composition of the diets during the depletion and repletion periods for the assessment of iron bioavailability (B), in the fortifying mixture, expressed as $\mathrm{g} / \mathrm{kg}$.

\begin{tabular}{|c|c|c|c|c|c|c|c|}
\hline \multirow{3}{*}{ Ingredients (g/kg) } & \multirow{2}{*}{\multicolumn{3}{|c|}{ Diets (A) }} & \multicolumn{4}{|c|}{ Diets (B) } \\
\hline & & & & \multirow{2}{*}{$\frac{\text { Depletion period }}{\text { SDWFe }}$} & \multicolumn{3}{|c|}{ Repletion period } \\
\hline & G1 & G2 & GFM & & SD & FMD & SDFeSu \\
\hline Cornstarch & 597.5 & 453.3 & 414.0 & 397.5 & 397.5 & 460.9 & 397.5 \\
\hline Casein $(83.2 \%)$ & 0.0 & 144.2 & - & 200.0 & 200.0 & 59.2 & 200.0 \\
\hline Fortifying mixture ${ }^{1}$ & - & - & 253.50 & - & - & 247.5 & - \\
\hline Dextrinizedstarch & 132.0 & 132.0 & 132.0 & 132.0 & 132.0 & 132.0 & 132.0 \\
\hline Saccharose & 100.0 & 100.0 & 100.0 & 100.0 & 100.0 & - & 100.0 \\
\hline Soyoil & 70.0 & 70.0 & - & 70.0 & 70.0 & - & 70.0 \\
\hline Microcrystallinecellulose & 50.0 & 50.0 & 50.0 & 50.0 & 50.0 & 50.0 & 50.0 \\
\hline Mineral mix & 35.0 & 35.0 & 35.0 & 35.0 & 35.0 & 35.0 & 35.0 \\
\hline $\mathrm{FeSO}_{4} \cdot 7 \mathrm{H}_{2} \mathrm{O}$ & - & - & - & - & - & - & 0.0694 \\
\hline Vitaminmix & 10.0 & 10.0 & 10.0 & 10.0 & 10.0 & 10.0 & 10.0 \\
\hline L-cysteine & 3.0 & 3.0 & 3.0 & 3.0 & 3.0 & 3.0 & 3.0 \\
\hline Cholinebitartrate & 2.5 & 2.5 & 2.5 & 2.5 & 2.5 & 2.5 & 2.5 \\
\hline BHT & 0.01 & 0.01 & 0.01 & 0.01 & 0.014 & 0.014 & 0.014 \\
\hline
\end{tabular}

Note: (A): G1: Protein-free diet; G2: Standard AIN-93G diet (with 12.00\% protein); GFM: Diet containing the Fortifying Mixture. (B): SDWFe: Standard Diet without Iron; SD: Standard AIN-93G Diet (containing 16.64\% protein); FMD: Diet containing Iron from the Fortifying Mixture; SDFeSu: Standard Diet containing Ferrous Sulfate as a source of iron at a concentration equivalent to the quantity of iron present in the fortifying mixture. ${ }^{1}$ According to Srebernich et al. [7].

determination. Animals with hemoglobin levels below $7 \mathrm{gdL}^{-1}$ were considered to be anemic $[15,17]$.

Repletion period: anemic rats were divided into three groups of five animals each according to weight and hemoglobin levels. The test diets (Table 1) were weighed daily and administered to the animals in a controlled manner (18g/day); deionized water was offered ad libitum, for 21 days. Weight gain and food consumption were recorded weekly for the calculation of FER. Hemoglobin and hematocrit were determined on the 21st day of repletion.

Biological iron utilization for the iron levels determined in the diet was calculated using the HRE\% method as proposed by Mahoney et al. [18] based on the following equation: $\mathrm{HRE}=\{(\mathrm{mg} \mathrm{HbFe}($ Final $)-\mathrm{mg} \mathrm{HbFe}($ Initial $) / \mathrm{mg}$ Fe consumed $\} \times 100$, where $\mathrm{mg} \mathrm{HbFe}=$ animal weight $(\mathrm{g}) \times 0.067 \mathrm{~mL}$ blood $/ \mathrm{g}$ body weight (considering that the blood volume corresponds to $6.7 \%$ of the animal's weight and that the hemoglobin molecule contains $0.335 \%$ iron) $x \mathrm{~g}$ $\mathrm{Hb} / \mathrm{mL}$ blood.

The relative biological values was obtained by dividing the slope $\left(a^{1}\right)$ of the line of the test diet (Fortifying mixture) by the slope $\left(a^{2}\right)$ of the SDFeSu line, as illustrated in Figure 1.

The study was approved by the Ethics Committee for the Use of Animals (Pontificia Universidade Católica de Campinas), Protocol $n^{\circ} 005 / 2012$.

Descriptive statistics were used to summarize and describe data as mean and standard deviation. Protein quality and iron bioavailability data were analyzed by Analysis of Variance (Anova) followed by the Tukey and Dunnett tests, with the level of significance set at $5 \%$ in both cases [19], using Statistical Package for the Social Sciences (SPSS Inc., Chicago, Illinois, United States) version 18.0. 


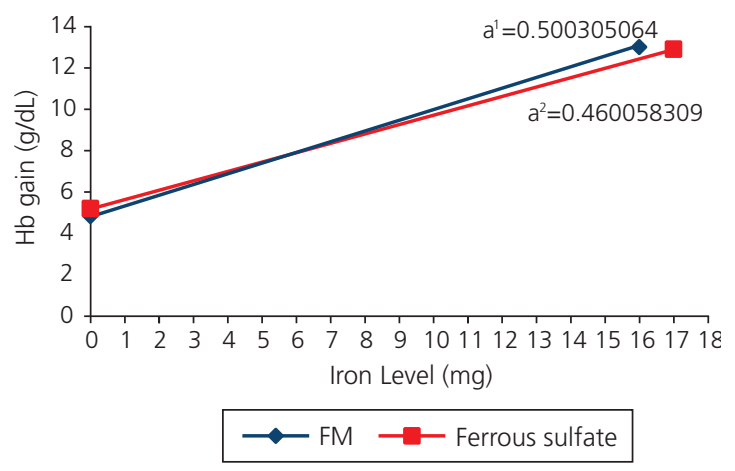

Figure 1. Determination of relative biological value by means of the angle coefficient of the lines, considering the initial and final blood iron and the hemoglobin gain of rats during the repletion phase.

Note: FM: Fortifying Mixture.

\section{RESULTS AND DISCUSSION}

Data regarding the centesimal composition $(\mathrm{g} / 100 \mathrm{~g})$ of the diets after their formulationsused for the protein quality assay reported as mean + standard deviation and expressed as dry basis for diet G1 (protein-free) were: ash 3.34 (0.07), protein $0.93(0.06)$, lipids $7.02(0.09)$, carbohydrate 88.71 (0.17); for diet G2 (AIN93G) were: ash 3.31 (0.06), protein 12.04 (0.11), lipids 7.05 (0.11), carbohydrate 77.60 (0.09) and for diet containing the Fortifying Mixture (GFM) were: ash 3.18 (0.04), protein 12.01 (0.08), lipids $7.14(0.10)$, carbohydrate 77.67 (0.09) respectively.

\section{Evaluation of protein quality}

Data regarding weight gain, food consumption, protein consumption and FER for the animals fed with diets protein-free, control (AIN-93G) and containing fortifying mixture (GFM) diet are listed in Table 2, as well as data regarding the determination of PER, Net Protein Retention (NPR), and true digestibility.

The results show that the animals receiving the G1 diet (protein-free) showed anegative meanweight gainof $-10.7 \mathrm{~g}$, indicating that, as expected, weight loss occurred during the experiment [20].

Comparison of the results obtained with the GFM diet (fortifying mixture) to those obtained with the $\mathrm{G} 2$ diet (standard casein diet) revealed that here was no significant difference $(p>0.05)$ in the parameters evaluated. This demonstrates the efficiency of the proteins present in the experimental diet regarding animal growth promotion and weight gain.

The test diet favored a good weight gain, suggesting that the animals had adapted to the consumption of a diet whose palatability did not affect its acceptability. Weight gain is not considered, of itself, to be an indicator of protein quality, although its results are reflected in the PER and FER, the same way as observed for diet and protein consumption. However, weight gain is known to be possibly related to water retention and to the synthesis of adipose tissue

Table 2. Data regarding Food Consumption (FC), Weight Gain (WG), Protein Consumed (PC), Feeding Efficiency Rate (FER), Protein Efficiency Rate (PER), Net Protein Retention (NPR), and True Digestibility (TD) for the animals fed a protein-free, control (AIN-93G) or FM diet. Data are reported as mean + standard deviation, $n=6$ per group.

\begin{tabular}{|c|c|c|c|c|c|c|c|}
\hline Diet/Group & $\mathrm{FC}(\mathrm{g})$ & WG (g) & $P C(g)$ & FER & PER & NPR & TD (\%) \\
\hline G1 (protein-free) ${ }^{1}$ & $94.6(9.2)$ & $-10.7(3.7)$ & $0.9(0.1)$ & $-0.12(0.05)$ & $-12.2(5.1)$ & - & - \\
\hline G2 (ain-93G) ${ }^{2}$ & $405.9^{(\mathrm{ns})}(57.1)$ & $183.2^{(\mathrm{ns})}(21.9)$ & $48.9^{\text {(ns) }}(6.9)$ & $0.45^{\text {(ns) }}(0.05)$ & $3.8^{(\mathrm{ns})}(0.4)$ & $3.5^{\text {(ns) }}(0.42)$ & $93.2^{\text {(ns) }}(3.3)$ \\
\hline GFM(fortifyingmixture) & $415.9^{\text {(ns) }}(47.3)$ & $201.8^{\text {(ns) }}(17.1)$ & $49.9^{\text {(ns) }}(5.3)$ & $0.49^{\text {(ns) }}(0.04)$ & $4.0^{(\text {ns) }}(0.2)$ & $3.623^{\text {(ns) }}(0.221)$ & $97.2^{\text {(ns) }}(3.7)$ \\
\hline LSD (5\%) - Tukey & 96.24 & 43.26 & 11.59 & 0.083 & 0.69 & 0.66 & 9.77 \\
\hline LSD (5\%) - Dunnett & 87.20 & 39.20 & 10.50 & 0.076 & 0.63 & 0.60 & 8.82 \\
\hline
\end{tabular}

Note: ${ }^{1}$ Protein-free diet used to calculate NPR and TD; ${ }^{2}$ Standard diet containing $12 \%$ protein (casein); LSD (5\%): Least Significant Difference at the $5 \%$ level of probability; ${ }^{(n s)}$ Nonsignificant according to the Tukey and Dunnett tests. 
due to the composition of the food consumed [21].

The animals fed the GFM diet ingested the same quantity as the animals receiving the G2 diet ( $p>0.05$ ), values corresponding to the expected consumption of approximately $15 \mathrm{~g} /$ day [22]. The mean daily consumption of the animals fed the standard diet (G2) and the test diet (GFM) showed not be statistically significant. The same was observed for weight gain, with no differences $(p>0.05)$ between the GFM (49.95g) and G2 (48.87g) groups. Also, for FER, there was nonsignificant difference between the GFM group (0.49) and the G2 group (0.45). These data indicate that the protein of the experimental GFM diet was utilized biologically as much as the standard AIN-93 protein (casein).

The evaluation of protein quality using PER and NPR revealed no significant difference $(p<0.05)$ between the $\mathrm{G} 2$ diet (with casein) and the GFM diet. The results obtained for $\mathrm{G} 2$ and GFM were 3.8 and 4.0 for PER and 3.5 and 3.6 for NPR, respectively. However, those differences were not statistically significant. Thus, it can be seen that the presence of pork liver in the diet promoted an increase in PER and NPR values. This fact can be explained by the higher food consumption and the consequent increase in the amount of protein consumed interfering with PER and NPR values, since the protein consumption and weight gain variables are used for the calculation of the two methods of biological evaluation.

Mendes et al. [23] detected PER and NPR values of 4.4 and 4.8 for chicken meat, 4.2 and 4.7 for fish, and 4.1 and 4.5 for pork meat, respectively, higher than the values obtained here for the $G 2$ diet (3.8 and 3.5), indicating that proteins of animal origin have a high biological value. Thus, chicken meat, fish and pork meat had higher PER and NPR values than those obtained here. Regarding true digestibility, although the values obtained with the GFM diet (97.2\%) were higher than those obtained with the G2 diet (casein), the difference between them was nonsignificant $(p<0.05)$.

\section{Bioavailability of iron in the fortifying mixture}

Depletion period: The hemoglobin and hematocrit results showed that all animals developed anemia at the end of the depletion period $\left(<7.0 \mathrm{mgdL}^{-1}\right)$.

Repletion period: The FER results obtained after the repletion phase are listed in Table 3. Anova showed that there was no significant difference between the test groups (FMD and SDFeSu) and that both groups had higher values of FER than the control group (standard diet).

A study that evaluated another protein source - mortadella - did not obtain the same result, but rather obtained better iron bioavailability for the control AIN-93G diet [23]. In a study of iron bioavailability in milk whey food supplements, Castro [24] observed that, during the repletion phase, the test diet (milk supplement containing $12 \mathrm{mg}$ of iron per $\mathrm{kg}$ ) resulted in higher FER values compared to its control diet containing heptahydrated ferrous sulfate. The author considered this result to be due to the addition to the supplement of other minerals responsible for growth and weight gain such as zinc, which helps palatability and improves appetite and is a co-factor for many enzymes responsible for growth. Other studies reporting similar results pointed out that qualitative differences in the proteins present in

Table 3. Food Efficiency Rate (FER) of the experimental groups of rats during the repletion phase ( $n=5$ per group).

\begin{tabular}{lc}
\hline Diet/Group & FER (mean+SD) \\
\hline Standard diet (AIN-93G) & $0,158(0.021)^{\mathbf{b}(\mathrm{ns})}$ \\
SDFeSu (withferrous sulfate) & $0,251(0.047)^{\mathbf{a}^{\mathbf{*}}}$ \\
FMD (fortifyingmixture) & $0.243(0.043)^{\mathbf{a}^{*}}$ \\
\hline LSD (5\%) - Tukey & 0.079 \\
LSD (5\%) - Dunnett & 0.068 \\
\hline
\end{tabular}

Note: ${ }^{1}$ Addition of $69.4 p p m$ Iron; SDFeSu: Reference group used for the Dunnett test (comparison of the individual means of the test groups to the reference group). Means followed by equal letters did not differ from one another $(p \geq 0.05)$ by the Tukey test (comparison of the means); ${ }^{(n s)}$ Nonsignificant; ${ }^{*}$ Significant by the Dunnett test. 
the different diets under study should also be considered, in addition to the different contents of other minerals [8,24-26].

Rat hemoglobin levels were determined at the beginning and at the end of the repletion phase, with the difference between these values characterizing hemoglobin gain. Table 4 lists the mean + standard deviation values of $\mathrm{GHb}$, iron consumption, ratio of hemoglobin gain per $\mathrm{mg}$ iron and HRE.

Hemoglobin gain (GHbin $\mathrm{g} / \mathrm{dL}$ ) was similar for the FMD and SDFeSu groups, with no difference by the Tukey and Dunnett tests, but differed from the control group (standard diet). Hemoglobin gain in relation to initial hemoglobin levels was $157.7 \%$ for the animals fed the FMD.

Hemoglobin gain was higher in the group receiving the diet containing heme iron compared to its respective control group receiving the diet containing ferrous sulfate. This was due to the fact that heme iron from products of animal origin (meats and derived products) has a higher absorption index since it crosses the cell membrane with an intact metalloporphyrin [24].

The Tukey testshowed that iron consumption was significantly lower in the control group (standard diet) compared to the SDFeSu and FMD groups, with no significant differences between the latter groups. Analysis by the Dunnett test revealed a significant difference between the FMD and standard diet (control) groups.

Regarding the ratio between hemoglobin gain and consumed iron ( $\mathrm{GHb} / \mathrm{Fe})$, the Tukey test revealed that the standard diet, FMD and SDFeSu groups did not differ significantly from one another, although the FMD group showed higher values than its respective SDFeSu control. When $\mathrm{GHb} / \mathrm{Fe}$ data were analyzed by the Dunnett test, the FMD and SDFeSu groups did not differ significantly from the standard diet group (control).

The hemoglobin regeneration (HRE\%) values detected were much lower and close to one another in the groups receiving the test diets (FMD and SDFeSu) compared to the control group (standard diet), as can be seen according to the data listed in Table 4. There was statistically nonsignificant differences between the test groups, but they were statistically different in relation to the control group (standard diet).

Since hemoglobin regeneration efficiency expresses the percentage of ingested iron that is absorbed, it can be seen that the group that received a greater quantity of iron showed a lower HRE value since the percentage of absorbed iron is inversely proportional to ingested iron, indicating lower iron absorption. A similar behavior was observed by Castro [24]

Table 4. Hemoglobin, iron consumption, consumption ratio and Hemoglobin Regeneration Efficiency (HRE) per animal group determined in blood collected on the first and 21st day of the repletion phase. Data are reported as mean + standard deviation and were compared by the Tukey and Dunnett tests at the $5 \%$ level of significance, $n=5$ per group.

\begin{tabular}{|c|c|c|c|c|c|c|}
\hline \multirow{2}{*}{ Diet/Group } & \multicolumn{3}{|c|}{ Hemoglobin (g/dL) } & \multirow{2}{*}{$\begin{array}{c}\text { Fe consumption } \\
(\mathrm{mg})\end{array}$} & \multirow{2}{*}{$\begin{array}{c}\text { Ratio } \\
(\mathrm{GHb} / \mathrm{Fe})\end{array}$} & \multirow{2}{*}{$\begin{array}{l}\text { HRE } \\
(\%)\end{array}$} \\
\hline & Initial & Final & Gain (GHb) & & & \\
\hline SD (AIN-93G (control) & $8.90(0.07)$ & $14.91(0.13)$ & $6.01(1.49)^{\mathbf{b}}$ & $12.49(0.23)^{\mathbf{b}}$ & $0.48(0.14)^{a}$ & $50.69(9.0)^{a}$ \\
\hline SDFeSu (withferrous sulfate) ${ }^{1}$ & $5.34(015)$ & $13.23(0.04)$ & $7.89(1.11)^{\mathbf{a}^{*}}$ & $17.15(0.27)^{\mathbf{a}^{*}}$ & $0.46(0.16)^{a(n s)}$ & $29.96(5.76)^{\mathbf{b}^{*}}$ \\
\hline FMD (fortifyingmixture) & $5.20(0.09)$ & $13.40(0.06)$ & $8.20(1.23)^{\mathbf{a}^{*}}$ & $16.39(0.33)^{\mathbf{a}^{*}}$ & $0.50(0.23)^{a(n s)}$ & $31.96(6.13)^{\mathbf{b}^{*}}$ \\
\hline LSD (5\%) - Tukey & - & - & 1.0 & 1.94 & 0.07 & 7.14 \\
\hline LSD (5\%) - Dunnett & - & - & 0.58 & 1.71 & 0.05 & 5.42 \\
\hline
\end{tabular}

Note: ${ }^{1}$ Addition of 69.4 ppm Fe; SDFeSu: Reference group used in the Dunnett test (comparison of the individual means of the test groups to the reference group). Means followed by equal letters did not differ from one another $(p \geq 0.05)$ by the Tukey test (comparison of the means); (ns) Nonsignificant; "Significant by the Dunnett test. 
and by Haro-Vicente et al. [27]. In their studies. HRE was also reduced, being higher in the standard diet group and lower in the SDFeSu group.

The use of food mixtures containing ingredients of high nutritional density has been successfully tested in Africa [28]. The cited authors pointed out that the main difficulty, in this case, is the cost of food. The liver used in the present study is among the pork products of lower cost, corresponding to less than $30 \%$ of the cost of a conventional cut of pork meat.

The relative biological values in the FMD (108\%) was calculated considering as standard the control diet containing ferrous sulfate (SDFeSu) with RBV 100\%.

In a study assessing a milk whey food supplement with inulin added and enriched with iron (12mg ferrous fumarate/100g), zinc, copper and vitamin A, Castro [24] obtained an RBV value of $76 \%$, while Navas-Carretero et al. [29], in a study on rats using cereals fortified with ferrous fumarate, obtained an RBV value of $95 \%$. In both studies, the values were lower than those obtained in the present study (108\%).

The relative biological value demonstrated that, although the two diets were formulated with the same iron concentration, iron availability was greater in the FMD. This may be explained by the fact that the main ingredient used in the FMD was of animal origin, a source of heme iron whose absorption is 2 to 3 times higher than that of non-heme iron [30].

In turn, ferrous sulfate is an orally administered medication extensively used for the treatment of iron deficiency which, however, consists of non-heme iron whose absorption may be impaired by inhibitory factors. Some studies have demonstrated difficulties regarding ferrous sulfate use, such as a prolonged treatment time with a consequent low adhesion, side effects such as nausea, abdominal cramps and constipation, occurring in about $20 \%$ of the patients submitted to this treatment, low adhesion to national programs of iron supplementation, and deficient iron distribution, among others [31-35]. Thus, the present similar results regarding HRE \% and RBV for the control group receiving ferrous sulfate and the group receiving the FM represent a positive aspect, demonstrating a similar bioavailability and the possibility of using the FM at day-care centers, favoring the absorption of non-heme iron present in the diet and facilitating the prevention of iron-deficiency anemia or the adhesion to its treatment.

The main limitations of this study are circumscribed discussion, due to the fact that very little research has been written about the fortification of foods with another food as a source of iron. This probably contributed by adding a quantity of other nutrients. Some unintentional contaminants may also have been added to the mixture. However, these failures were successfully overcome with the use of controls for the preparation of the diet and the standardization of the mixtures.

In powder form and not requiring cooking or heating, the fortifying mixture can be easily added to soups, creams, cooked meats and mainly beans, which represent a basic dietary preparation practically throughout the Brazilian territory. Thus, its daily use at day-care centers is a positive and promising aspect for the prevention and control of iron-deficiency anemia in humans, especially children of school age. This is a product with a strong chance of being used for school meals and with the consequent potential of being included in the National School Feeding Program, after a acceptability test with humans.

\section{CONCLUSION}

The fortifying mixture made from pork liver proved to be a product with a high PER value of 4.04 and high RBV of iron, equivalent to $108 \%$ compared to ferrous sulfate. 


\section{CONTRIBUTORS}

All authors participated in all phases of the research article.

\section{REFERE NCES}

1. Bruins M, Mugambi G, Verkaik-Kloosterman J, Hoekstra J, Kraemer K, Osendar S, et al. Addressing the risk of inadequate and excessive micronutrient intakes: Traditional versus new approaches to setting adequate and safe micronutrient levels in foods. Food Nutr Res. 2015;59:26020. https://doi. org/10.3402/fnr.v59.26020

2. Aaron GJ, Dror DK, Yang Z. Multiple-micronutrient fortified non-dairy beverage interventions reduce the risk of anemia and iron deficiency in schoolaged children in low-middle income countries: A systematic review and meta-analysis (i-iv). Nutrients. 2015;7(5):3847-68.

3. Gibson SR. Enhancing the performance of foodbased strategies to improve micronutrients status and associated health outcomes in young children from poor resource households in lowincome countries: Challenges and solutions. In: Thompson B, Amoroso L, editors. Improving diets and nutrition. Rome: Food and Agriculture Organization of the United Nations; 2010. p.19-31.

4. Zotor FB, Ellahi B, Amuna P. Applying the food multimix concept for sustainable and nutritious diets. Proc Nutr Soc. 2015;74(4):505-16.

5. Mujifc-Coopman MF, Brito A, López de Romaña D, Ríos-Fcstillol, Coris H, Olivares M. Prevalence of anemia in Latin America and the Caribbean. Food Nutr Bull. 2015;36(2Suppl.):S119-28.

6. Elmadfa I, Meyer AL. Vitamins for the first 1000 days: Preparing for life. Int J Vitam Nutr Res. 2012;82(5):342-7.

7. Srebernich SM, Gonçalves GMS, Domene SMA. Fortifying pork liver mixture: Preparation and physicochemical characteristics: Part 1. Food Sci Technol. 2017;37(4). Epub Jul 20, 2017. https:// doi.org/10.1590/1678-457x.13517

8. Reeves PG, Nielsen FH, Fahey Jr. GC. AIN-93 Purified diets for laboratory rodents: Final report of the American Institute of Nutrition ad hoc writing committee on the reformulation of the AIN-76A Rodent Diet. J Nutr. 1993 [cited 2016 Jul 1];123(11):1939-51. Available from: http://jn. nutrition.org/content/123/11/1939

9. Horwitz W, edtior. Official methods of analysis of the Association of Official Analytical Chemists. 17th ed. Gaithersburg: Association of Official Analytical Chemists; 2000. v.2.
10. Instituto Adolfo Lutz. Normas analíticas do Instituto Adolfo Lutz: métodos físico-químicos para análise de alimentos. 5th ed. São Paulo: IAL; 2008. v. 1

11. Pellet PL, Young VR. Evaluation of protein quality in experimental animals. In: Nutritional evaluation of protein foods. Tokyo: The United Nations University; 1980. p.41-57.

12. Hegsted DM. Protein quality and determination. In: Whitaker JR, Tannenbaum SR, editors. Food protein. Westport: AVI Publishing; 1977. p.347-62.

13. Fritz JC, Pla GW, Harrison BN, Clark GA. Estimation of the bioavailability of iron. J Assoc Off Anal Chem.1975;58(5):902-5.

14. Feltrin C, Morais MB, Freitas KC, Morais TB, Fagundes Neto $U$, Amancio OMS. Effect of soluble fiber pectin on growth and intestinal iron absorption in rats during recovery from iron deficiency anemia. Biol Trace Elem Res. 2009;(129):221-8.

15. Lima AO, Soares JB, Gre JB. Métodos de laboratório aplicador a clínica: técnica e interpretação. $8^{\mathrm{a}}$ ed. Rio de Janeiro: Guanabara Koogan; 2001.

16. Nelson D, Morris M. Exame básico do sangue. In: Henry JB, editor. Diagnósticos clínicos e tratamento por métodos laboratoriais. São Paulo: Manole; 1995. p.641-99.

17. McKay RH, Higuchi DA, Winder WW, Feel RD, Brown EB. Tissue effects of iron deficiency in the rat. Biochim Biophys Acta.1983;757(3):352-8.

18. Mahoney AW, van Orden CC, Hendricks DG. Efficiency of converting food iron into hemoglobin by the anemic rat. Nutr Metab. 1974;17(4):223-30.

19. Statsoft INC. Statistica for Windows [Computer Program Manual]. Tulsa (OK): StatSoft Inc; 2000 [2016 Oct 14]. Available from: http://www.statsoft. com

20. Pires ISC, Costa NMB, Rosado GP, Oliveira RS, Monteiro JBR. Qualidade protéica da carne de novilho precoce alimentado com lipídios protegidos. Ciênc Tecnol Aliment. 2006;26(4):799-804.

21. Fontes PR. Valor protéico, biodisponibilidade de ferro e aspectos toxicológicos mortadelas formuladas com sangue tratado com monóxido de carbono [tese]. Viçosa: Universidade Federal de Viçosa; 2006.

22. Ritskes-Hoitinga $M$, Chwalibog A. Nutrient requirements, experimental design, and feeding schedules in animal experimentation. In: Hau J, Van Hoosier GL, editors. Handbook of laboratory animal science. 2nd ed. Boca Raton: CRC Press; 2003. p.1-30. v.1.

23. Mendes FQ, Oliveira MGA, Pires CV, Costa NMB, Hoffman ZB. Qualidade protéica de diversos 
alimentos incluindo diferentes variedades de soja. Alim Nutr. 2009;20(1):77-86.

24. Castro LCV. Efeitos da intervenção com suplemento alimentar à base de soro de leite adicionado de prebiótico no estado nutricional de ferro e vitamina A em pré-escolares [tese]. Viçosa: Universidade Federal de Viçosa; 2010 [acesso 2016 jul 7]. Disponível em: http://www.tede. ufv.br/tedesimplificado/tde_arquivos/38/TDE2010-10-29T082606Z-2623/Publico/texto\%20 completo.pdf

25. Ybarra LM, Costa NMB, Ferreira CLL. Interação cálcio e ferro: uma revisão. Nutrire. 2001;22:85-107.

26. Boaventura GT, Silva RHL, Tostes LF, Azeredo VB. Ganho de peso, hemoglobina e hematócrito de ratos recebendo dieta de Quissamã, RJ, com ou sem suplemento alimentar alternativo. Rev Nutr. 2003;16(3):321-31. https://doi.org/10.1590/S141 5-52732003000300010

27. Haro-Vicente JF, Rez-Conesa D, Braqueh FR, Ros G. Iron absorption and haemoglobin status of rats fed a ferrous bisglycinate-fortified growing-up milk. J Sci Food Agric. 2009;89(12):2107-14.

28. De Carvalho IST, Granfeldt Y, Dejmek P, Håkansson A. From diets to foods: Using linear programming to formulate a nutritious, minimum-cost porridge mix for children aged 1 to 2 years. Food Nutr Bull. 2015;36(1):75-85.

29. Navas-Carretero $S$, Sarriá B, Péres-Granados AM, Schoppem S, Izquierdo-Pulido M, Vaquero MPA. Comparative study of iron bioavailability from cocoa supplemented with ferric pyrophosphate or ferrous fumarate in rats. Ann Nutr Metab. 2007;51(3):204-7. https://doi.org/10.1159/0001 04138

30. Zimmermann MB, Hurrel RF. Nutritional iron deficiency. Lancet. 2007 [cited 2016 Jul
6];370(9586):511-20. Available from: http://www5. medicine.wisc.edu/ williams/nutritional_iron_ deficiency_2007.pdf

31. Gillespie SR, Mason JB, Kevany J. Controlling iron deficiency: Nutrition policy discussion. Geneva: WHO; 1991 [cited 2016 Jul 1]. Available from: http://www.unscn.org/layout/modules/resources/ files/Policy_paper_No_9.pdf

32. Torres MAA, Sato K, Juliano Y, Queiroz SS. Terapêutica com doses profiláticas de sulfato ferroso como medida de intervenção no combate à carência de ferro em crianças atendidas em unidades básicas de saúde. Rev Saúde Pública. 1994;28(6):410-5.

33. Cardoso MA, Penedo MVC. Intervenções nutricionais na anemia ferropriva. Cad Saúde Pública. 1994 [acesso 2016 jul 8];10(2):231-40. Disponível em: http://mww.scielo.br/pdf/csp/v10n2/v10n2a10. pdf

34. Monteiro CA, Szarfarc SCA prescrição semanal de sulfato ferroso pode ser altamente efetiva para reduzir níveis endêmicos de anemia na infância. Rev Bras Epidemiol. 2002;5(1):71-83.

35. Coutinho GGPL. Eficácia do procedimento de suplementação com ferro em ciclos para redução da anemia em pré-escolares [tese]. São José do Rio Preto: Faculdade de Medicina de São José do Rio Preto; 2009 [acesso 2016 jul 5]. Disponível em: http://bdtd.famerp.br/tde_arquivos/1/TDE-201005-05T081810Z196/Publico05T081810Z196/ Publico/05T081810Z196/Publico/geraldogaspar paeslemecoutinho_tese.pdf
Received: May 3, 2017

Final version: August 30, 2017

Approved: September 22, 2017 